\title{
The Psychological State of Farmers in the Agricultural Cultivation of Food Crops during the COVID-19 Pandemic in Java, Indonesia
}

\author{
Rafika Nur Kusumawati $^{1 *}$, Kharisma Kusuma Wardani ${ }^{2}$ and Suntoro ${ }^{3}$ \\ ${ }^{1}$ Department of Psychology, Faculty of Medicine, Universitas Sebelas Maret, Surakarta, Indonesia; \\ ${ }^{2}$ Department of Agriculture and Food Security, Klaten, Indonesia; ${ }^{3}$ Department of Soil Science, \\ Faculty of Agriculture, Universitas Sebelas Maret, Surakarta, Indonesia \\ ${ }^{*}$ Corresponding author: rafika.nurk@staff.uns.ac.id
}

\begin{abstract}
This research aims to discover the psychological state of farmers in the agricultural cultivation of food crops during the COVID-19 pandemic. It is a descriptive explorative study which explores the farmers' opinions regarding their agricultural activities during the COVID-19 pandemic which reached its peak between March and June 2020. During this period, a Large Scale Social Distancing (LSSD) system was enforced in some areas. The data collection was conducted in June 2020 before the implementation of the new normal, involving 634 respondents which spread across 40 districts throughout Java. Throughout the COVID-19 pandemic period, almost all farmers continued to carry out their agricultural activities. Some farmers had implemented the health protocols. According to most farmers' opinions, doing the agricultural activities made them healthier. With regard to COVID-19, most farmers behave normally, while the rest feel worried. Agricultural extension activities are constrained and hampered by the implementation of physical and social distancing, especially large-scale social restrictions. Seeing the psychological condition of the farmers, where most are continuing to cultivate food crops and only slightly worried about the COVID-19 pandemic, gave hope for the sustainability of agricultural production in the new normal period.
\end{abstract}

Keywords: agricultural cultivation; COVID-19 pandemic; food crops; psychology of farmers

Cite this as: Kusumawati, R. N., Wardani, K. K., \& Suntoro. (2021). The Psychological State of Farmers in the Agricultural Cultivation of Food Crops during the COVID-19 Pandemic in Java, Indonesia. Caraka Tani: Journal of Sustainable Agriculture, 36(1), 58-68. doi: http://dx.doi.org/10.20961/carakatani.v36i1.43638

\section{INTRODUCTION}

The COVID-19 disease has developed into a pandemic, starting with a small chain of spread, which then culminates in a larger chain in many countries resulting in its spread around the world. Currently, the US is the country worst affected by the COVID-19 pandemic. The rapid spread of COVID-19 around the world has left people afraid, panicked, concerned and anxious (Shammi et al., 2020). Such situation also occurred in the Indies farmers and they became mentally stressed because there were no people to harvest their goods. Cultivated products such as vegetables, fruits, flowers, species etc. cannot be exported overseas which will affect their economy (Varalakshmi and Swetha, 2020).

The National COVID-19 Task Force team, said that until the end of August 2020, the development of COVID-19 in the districts was better than in the cities; this was due to: (1) the population, which was more dense in the cities, 55 percent of Indonesia's population was in cities, (2) in urban areas there are more places that allow people to gather in large numbers (such as malls and entertainment venues)

\footnotetext{
* Received for publication August 11, 2020

Accepted after corrections October 10, 2020
} 
(Nugraheny, 2020). The same thing happened in the Philippines, there were fewer cases of COVID-19 in several provinces far from metropolitan cities (Kahambing and Edilo, 2020). The impact of the COVID-19 lockdown has resulted in food and nutrition shortages in the most poverty-vulnerable groups due to heavy livelihoods (Shammi et al., 2020). The sustainability of agricultural production must persist. In Italy, the impact of the lockdown in the agri-food sector was that a quantity of entrepreneurs, are having difficulties in obtaining labor. This issue is very important, because in agri-food sector, the labor are working in all of the aspects in food production. There is no doubt that the primary sector, especially agriculture and food which is also related to industry, is very strategic and important. Therefore, the sustainability of this sector must be maintained (Barcaccia et al., 2020).

It is a fact that the COVID-19 pandemic causes psychological stress (World Health Organization, 2020). In the larger community, it may have a variety of psychological impacts, such as anxiety, stress and worry, as a result of news about the increasing number of COVID-19 victims. Inaccurate or misleading news can trigger psychological stress which in turn affects the stress hormones (Effendi et al., 2020). Stress is a common problem that occurs in the lives of human beings and can afflict anyone anywhere. Problems arise when people experienced a particularly large amount of stress. The effect of stress can jeopardize physical and mental health and an excessive amount of stress can present a danger to each one of us (Lumban Gaol, 2016).

Based on a concept introduced by Cannon, namely the fight-or-flight response, stress can be defined as a bodily response to some stimuli (Lumban Gaol, 2016). The impact of COVID-19 has shown that the current pandemic is both aggravating the already existing stresses and at the same time creating new stressors; with potentially serious consequences that may worsen preexisting health conditions (Lemke et al., 2020). Anxiety is defined as an emotional condition that causes discomfort characterized by feelings of worry, anxiety and fear so that it can interfere with life (Annisa and Ifdil, 2016). The results of a research in Saudi Arabia on students, showed that the impact of Corona Virus (MERS-CoV) were $77 \%$ reported minimal anxiety, $18.4 \%$ reported mild anxiety, $4.6 \%$ reported moderate anxiety and none of them reported severe anxiety (Al-Rabiaah et al., 2020).

In general, individuals who experience stress will have difficulties in managing their lives; because stress will lead to anxiety and send the nervous system out of control. The nerve centers in the brain will activate the sympathetic nerves, which in turn will encourage a secretion of the adrenaline and cortisol hormones, which ultimately mobilizing the other hormones in the body. When an individual is living in a stressful situation, his or her physiological condition will encourage the release of sugars from the liver and the breakdown of body fats, thus increasing the fat content in the blood.

This condition will lead in increasing blood pressure and more blood to be redirected from the digestive system to the muscles, leading to an increase in the production of gastric acid, making the stomach feel bloated and nauseous (Haqi et al., 2019). Anxiety about death is a human psychobiological condition that is inherited from human ancestors. Thus, human action will lead to efforts to maintain life and avoid things that can threaten life (Zariayufa et al., 2019). In stress management theory, stress management techniques and how subjects respond to stressors are very much influenced by the stage of development that is being undertaken (Haqi et al., 2019).

The stress that arises during the time of the COVID-19 pandemic may be in the form of: 1. Fear and anxiety about a person's own health or the health of a loved one; 2. Changes in a person's sleep pattern and/or eating pattern; 3. Difficulty sleeping and concentrating; 4. Deterioration of the physical health of a person with a preexisting chronic illness and/or psychological disorder; 5. Increase in use of medication (Centre for Disease Control and Prevention, 2020).

In normal conditions, Java Island agriculture is a national food buffer (Waridin, 2015). With the COVID-19 pandemic, there will be shocks regarding food sectors which is a concern of national food security. The COVID-19 pandemic played roles in major economic shocks, particularly on the resilience of the agri-food sector during this period (Hossain, 2020), especially in developing countries where selfemployment, wage-workers and informal workers are threatened by the disruption of food supply chains, movement restrictions and trade (Barcaccia et al., 2020). March 2020 was the 
start of the implementation of the Indonesian government's policy to work and study from home (Yulianti et al., 2020). The pandemic resulting from the appearance of a new type of corona virus, known as COVID-19, is today still far from being over. The World Health Organization has issued a warning, calling upon all countries in the world to be better prepared to deal with the virus. The Indonesian government clearly needs to give its full attention to the agricultural sector in the midst of this COVID-19 pandemic (World Health Organization, 2020). Without safeguarding the fundamental needs for the vulnerable ultra-poor group, it can undeniably cause the socioeconomic crisis and mental stress due to the COVID-19 lockdown (Shammi et al., 2020).

This issue needs to be addressed, because in the conditions of the COVID-19 pandemic, food supply must continue, because food is the main necessity of life. The COVID-19 pandemic has an impact on health, social, economic and psychological conditions. The psychological condition of farmers in carrying out crop cultivation activities greatly determines the sustainability of agricultural production. By looking at the psychological condition of the farmers, it can be used to properly formulate strategies as guidance and assistance to farmers in the new normal period, so that sustainable agriculture and food availability can be maintained. The purpose of this study was to determine the psychological state of farmers in food crop farming activities. This study is to explore the opinions of farmers about carrying out their agricultural activities during the COVID-19 pandemic which reached its peak between March and June 2020, prior to the implementation of the new normal, specifically on the psychological state of farmers similar to study conducted by Bennett (2016) and Harlianty et al., (2019).

\section{MATERIALS AND METHOD}

This study was a descriptive explorative study. During the pandemic period, a Large Scale Social Distancing (LSSD) system was enforced in some areas (Djalante et al., 2020; Pragholapati, 2020; Setiati and Azwar, 2020). Therefore, it is necessary to accurately describe the impact of the lockdown on farmers' psychology that determines the production chain of the agri-food sector at the national level, in order to develop successful ideas and efficient strategies for post-COVID-19 recovery in the agricultural sector (Barcaccia et al., 2020).

The variables observed in this study including sociodemographic such as farmers' education level, food crop commodities cultivated by most farmers in Java (such as rice, vegetables, secondary crops and intercropping) and access to farmers about their agricultural activities during the pandemic, farmers' motivation to keep on conducting fields' activities (respondents who are required to choose more than one answer), the efforts made by farmers to protect themselves from COVID-19, the farmers' state of mind when carrying out farming activities with regard to COVID-19 and the role of extension workers during the pandemic. Questionnaires were collected in a standardized manner (Simha et al., 2017; Akter et al., 2018).

The data of this research was collected online with Google forms. Informal discussions were performed, in order to understand farmer's circumstances, practices and constraints (El Sheikh et al., 2017). Randomized face-to-face interviews were conducted by surveyors who interviewed farmers, who then entered the data into a Google form (Simha et al., 2017). The results of the data in the Google form will be displayed in the form of a percentage of farmers' opinions. It included a total of 634 respondents which covered 40 districts in Java Island, Indonesia. The number of samples is based on farmer representation so that it will produce an accurate results.

\section{RESULTS AND DISCUSSION}

This study revealed that commodities produced by the respondents of this research were rice $(54.7 \%)$, vegetables $(21.3 \%)$, secondary crops $(16.2 \%)$ and inter-cropping (7\%). Lowland rice is a commodity that is widely cultivated by farmers in Indonesia, especially on the island of Java, hence, they can describe the actual conditions better. The education levels were dominated by Elementary School (38.8\%), followed by Middle School (23.5\%) and High School (24.6\%) with $6.5 \%$ of respondents having no formal education and $6.6 \%$ holding a university degree. Farmers' community was dominated by low educational levels, their ability to capture and digest various information is low. This will act as an inhibitor in following 
the developments in the existing conditions, including COVID-19.

In developing countries, where most of the people work in the agricultural sector, the impact of COVID-19 is obvious; as in Bangladesh, most of the impact were seen on low-income people (Shammi et al., 2020). The farmers got mentally stressed for the reason lack of labor for harvesting their crops. The cultivated products such as vegetables, fruits, flowers, species etc. cannot be exported to the foreign countries which will affect their economy.
This research studied the condition of Indonesian farmers in relation to the COVID-19 pandemic. Out of the 634 respondents, 99.6\% were continuing with their agricultural activities. Of this $99.6 \%$ who were continuing with their agricultural activities, $24.8 \%$ were adhering to health protocols, while $64.7 \%$ were continuing to carry out their activities as usual. Meanwhile, $10.1 \%$ of the respondents had reduced their agricultural activities. Only $0.4 \%$ were no longer continuing with their agricultural activities (Figure 1).

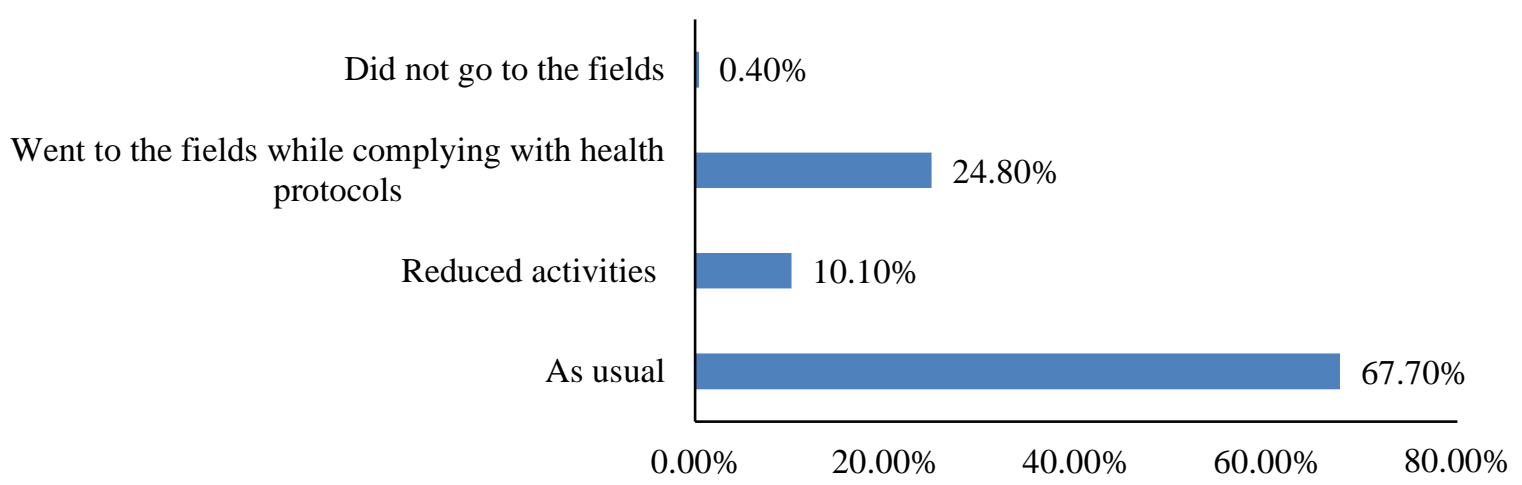

Figure 1. Agricultural activities during the COVID-19 pandemic

The farmers believe that since agricultural cultivation is their main job as well as their responsibility; hence, in the current conditions they should still carry out these activities. For the farmers whom have continued to carry out their agricultural activities as usual, the reason was that they believe cultivating the land does not have any effect on their health, or simply that they are unaware of the danger of COVID-19. In performing their agricultural work, only $35.3 \%$ of all respondents were either aware of health protocols, had reduced their activities, or were no longer carrying out their activities in the field.

It is common knowledge that the government's instructions to practice physical distancing and other health protocols have been widely made known through various media. Some of the health protocols include wearing masks, washing hands frequently and keeping a distance from other people. With a view to this response, compliance to government advice is unique amongst farmers. Compliance as the degree to which a person adheres to and follows medically assigned health procedures (Lutfey and Wishner, 1999). Compliance is the awareness of an individual to practice the recommendations given to the individual, even without monitoring by the person giving the advice. This means that the awareness of the farmers is something quite interesting and is of course influenced by a number of factors, such as the acquisition of information, the desire of the individual and the obedience and consistency of the farmers in complying with these regulations.

The research results showed that the majority of the farmers $(64.7 \%)$ who had been continuing with their usual activities were not adhering to government advice or health protocols. A person's compliance to a request, suggestion, or health recommendation arises because of the individual's belief that something is posing a threat to his or her health. This is explained using the Health Belief Model (HBM) theory, which refers to an individuals' personal belief in the threat of a disease and its transmission, including the seriousness of the disease and the person's vulnerability to the disease, so that the individual perceives benefit from the recommendations of a health practitioner because he or she can avoid the disease (Jones et al., 2015). We know that the corona virus is a new virus for which there is yet any cure. In addition, the number of deaths from the virus is very high. These two facts are perceived as the greatest threat by individuals who 
treat this virus seriously. Belief that the disease is dangerous is one of the key factors that makes a person either comply or not comply with the given health recommendations.

Apart from HBM, another theory that can explain about a person's compliance with health recommendations is the Theory of Planned Behavior (TPB), in which the main focus is a person's intentions. There are 3 important aspects in this theory, namely attitude towards behavior, subjective norms of behavior and behavioral control (Mahmud and Uyun, 2016). Attitude towards behavior is strongly influenced by belief in the final outcome, which in this case is a person's health, or avoidance of the corona virus. The subjective norms of behavior are influenced by the views of people around an individual and the motivation that supports the emergence of an individual's compliance. This means that compliance is also strongly influenced by how the surrounding environment supports an individual to comply with existing advice or recommendations. The final aspect is concerned with the ability of a person to control his or her behavior so as to continue to comply with the given health recommendations.
The farmers' persistence in continuing with the agricultural cultivation is due to the belief that their activities have no bearing on the onset of COVID-19. Based on the opinions of the farmers, $98.9 \%$ of the respondents who decided to continue their farming activities in the field stated that they believed it had no effect on the possibility of becoming infected by COVID-19 and only $1.1 \%$ believed it would be feasible to catch the COVID-19 disease. In fact, $51.4 \%$ of the respondents stated that carrying out their agricultural cultivation activities would actually make them healthier, since it was a form of exercise and $33.6 \%$ believed they were healthier because they were getting more vitamin D to help boost their immune system (Figure 2). According to Mutiarachmah and Maryatmi (2019), there is a significant positive relationship between optimism and psychological well-being. Individuals who work happily will have positive feelings at all times, because they are able to manage and control the work so as to maximize performance and provide happiness (Nandini, 2016). Optimists are quicker to accept the reality of a challenge and cope difficult live (Snyder and Lopez, 2002).

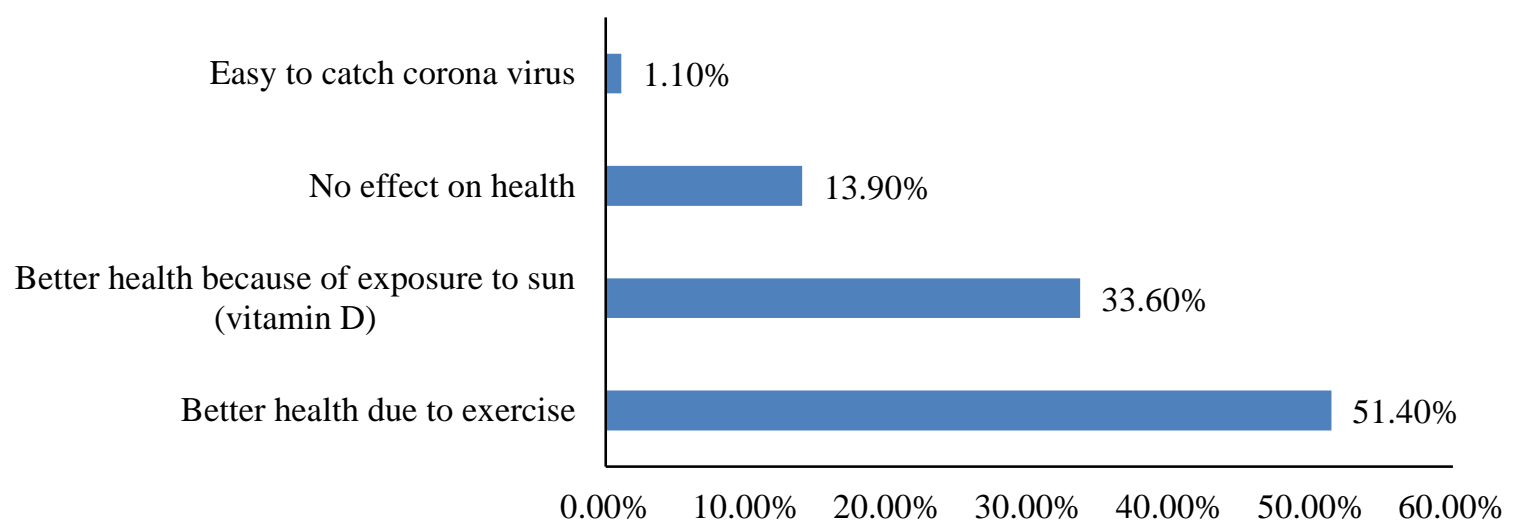

Figure 2. Farmers' opinions about their agricultural activities

A person's conviction that he or she will be able to avoid anxiety is a way of preserving the mental state in dealing with COVID-19. Certain beliefs, such as exercising to stay healthy and getting more vitamin $\mathrm{D}$ from the sun, demonstrate the farmers' spirit in coping with the pandemic. This shows evidence of positive affect in dealing with the current situation. Positive affect is a feeling that reflects a level of pleasurable involvement with the environment (Clark et al., 1989). There is a consistent pattern in several studies about positive affect which connected to physical health (Cohen and Pressman, 2006).

Lindfors and Lundberg (2002) prove that a positive psychological condition can lower the release of the cortisol hormone. A number of studies have found that positive affect can lower the morbidity rate and the appearance of symptoms and pain (Cohen and Pressman, 2006). This has the effect of lowering the hormone cortisol which is the main stress hormone related 
to various pathological conditions (Steptoe et al., 2005); cortisol has the ability to make a person more calm and relaxed (Pressman and Cohen, 2005). COVID-19 is caused by a virus that attacks human's immune system. That positive affect (PA) has very significant connections with the immune and cardiovascular systems (Pressman and Cohen, 2005), proves that a person's immune system will be affected by their feelings (affect). When a person is able to be high-spirited, happy, enthusiastic, calm and relaxed, his or her level of immunity will go up, which can act as an antidote to the virus in this time of pandemic.

The reason why farmers continue to carry out their agricultural cultivation is to provide them with subsistence to meet their daily needs. This can be seen from Figure 3, 79.20\% of farmers answered that they had to fulfill their daily needs. There are several reasons for someone to work, one of which is to make ends meet or financial necessities (Smith, 1975). The agricultural business is their main source of livelihood; hence, if their agricultural activities came to a halt, they will have no source of income. In addition, farming is a routine activity that they do daily, so it would feel strange not to be performing their usual activities. There are 5 reasons for someone to work, one of which is that work is a habit (Smith, 1975). Another reason why they continue with their agricultural activities is to prevent the land from becoming neglected if it is left unplanted.

In Figure 3, it is seen that $53.50 \%$ of the farmers answered that the land was not neglected. In addition, $3.60 \%$ of the farmers answered that their reason was for meeting their friends and $7.20 \%$ answered that they were bored at home. In addition to earn income and living activities, the function of work is to identify, connect or associate with other people or jobs and having meaningful life experiences (Smith, 1975). Relationship or association with other people at work is one of the things that motivates a person to work.

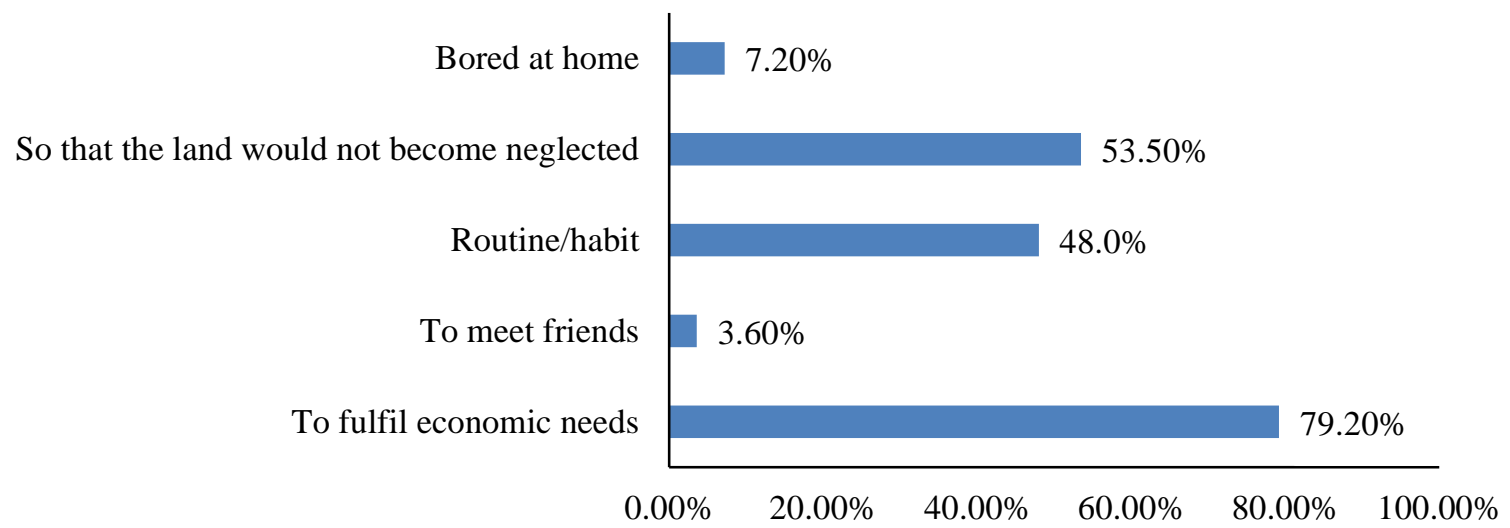

Figure 3. Motivation of farmers for continuing to go to the fields (respondents were allowed to choose more than one answer)

Health is closely related to one's attitude towards life's problems. In this pandemic condition, psychologically accepting emotional events tends to increase emotional resilience and reduce stress (Acharibasam and Anuga, 2018). An optimistic attitude about life can promote good health and even accelerate the healing process when recovering from a serious illness or facing a situation like the current COVID-19 pandemic. The attitudes that appear to be most helpful are optimism, hope and above all the feeling that this has an impact on the quality of life itself. Throughout the COVID19 pandemic, the health conditions of $95.4 \%$ of the farmers were good, with no fever or cough reported, while $4.6 \%$ suffered from a fever or cough but none of them showed any indication of being infected with COVID-19. This proves that people conducting agricultural activities are not susceptible of the danger for becoming infected by COVID-19, as long as health protocols continue to be adhered to, such as wearing a mask, keeping a distance and washing hands or bathing after returning home from the field.

An attitude of optimism, while continuing to pay attention to health protocols, makes it more likely for a person to avoid catching 
COVID-19. With regard to these health protocols, the research results show that in carrying out their activities during the COVID-19 pandemic, $58.7 \%$ of the farmers washed their hands every time they finished work, while only $22.2 \%$ wore masks and $19.1 \%$ did not wear masks because they felt obstructed or uncomfortable in their work (Figure 4).

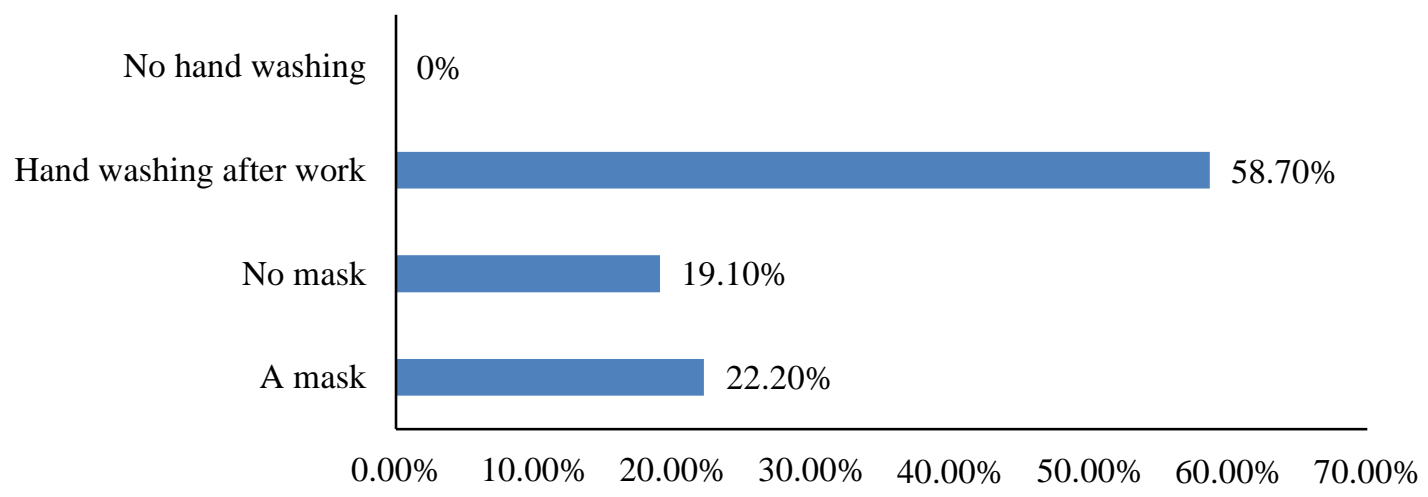

Figure 4. Efforts made by farmers to protect themselves from COVID-19

The farmers got mentally stressed for the reason of lack of people for harvesting their goods. The cultivated products like vegetables, fruits, flowers, species etc. cannot be exported to the foreign countries which will affect their economy (Varalakshmi and Swetha, 2020). When the COVID-19 pandemic struck, the human mind became one of its victims. Information and news about the increasing number of COVID-19 victims from one day to another can potentially have a serious impact, leading to stress, fear and anxiety in the community. Anxiety about the consequences of COVID-19 is an aspect of the COVID-19 pandemic that is often ignored. The COVID-19 pandemic has caused another problem, namely a pandemic of anxiety that will lead to stress. Stress is an environmental situation that a person perceives to be so oppressive that the individual in question is only able to accept the stress stimulus directly without any process of evaluation (Lumban Gaol, 2016).

With regard to the farmers' feelings, the research results show that while carrying out their agricultural activities during the situation of the pandemic, $36.6 \%$ of the farmers felt anxiety (Figure 5). The COVID-19 pandemic makes people stressed because they are afraid and anxious about the new disease; about how great its impact might be and because they do not know when it will end. Inaccurate news from various mass media can sometimes trigger anxiety, while health protocols such as social distancing can make people feel isolated and lonely, thus increasing levels of stress and anxiety. Anxiety occurs when a person has a problem that they feel unable to solve, thus leading to feelings of frustration due to a lack of control (Sadaghiani and Sorkhab, 2013).

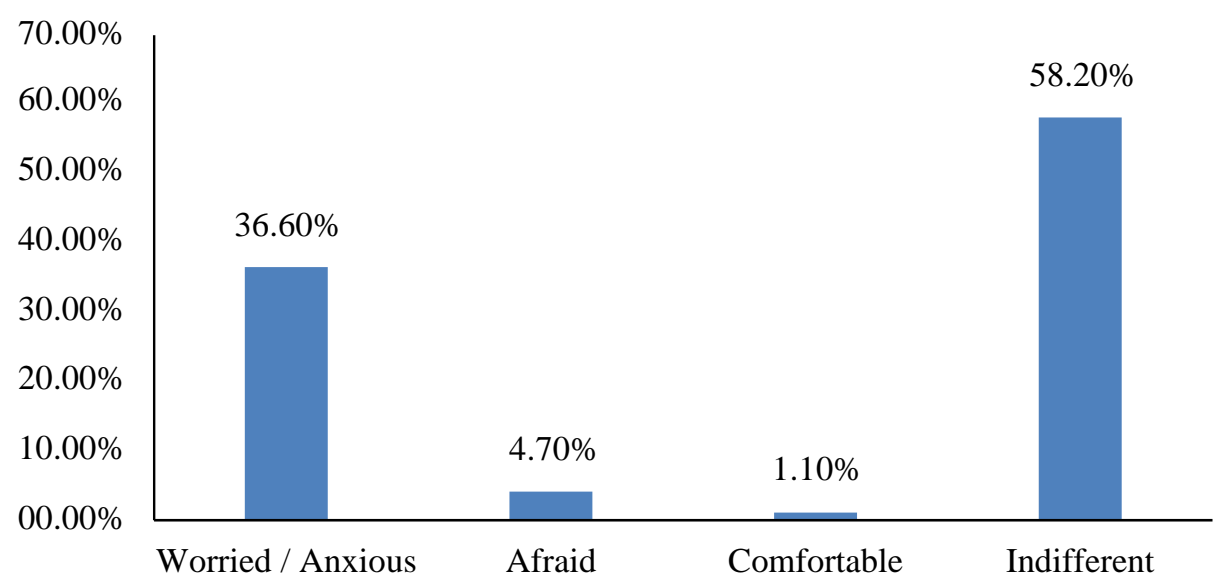

Figure 5. Farmers' feelings while carrying out their farming activities 
Anxiety, fear and panic are all parts of the mental health risks that cannot be avoided by people who are being monitored for the disease. These psychological risks can cause a person's health condition to deteriorate. Therefore, it is suggested that people minimize watching, reading, or listening to news about COVID-19 that causes anxiety or stress and seek information only from reliable sources. In this kind of condition, law enforcement's act against irregularities is the most appropriate action (Varalakshmi and Swetha, 2020), including the dissemination of false information that disturbs the public. As was the case in the Indies, if anyone created a panic situation due to the spread of false information in any way, for example: sharing any information on social media is punishable by a prison sentence (Varalakshmi and Swetha, 2020). However, the research results showed that the majority of farmers, or $58.2 \%$, stated that they felt fine and did not feel any anxiety. Agricultural extension plays an important role in identifying the various needs and problems the farmers face and communicating these problems to the farmers so that they can accept and apply them accordingly.

The activities of counselling for the farmers done by an agricultural agent are really hampered due to physical and social distancing. Mass gathering of people at this time is strictly prohibited. Meanwhile, the counselling activities is often carried out by gathering a group of farmers. In addition, the implementation of work from home also reduce the activity of counselling. This situation will affect the performance of the agents. Based on previous research, the performance of an agricultural agent is very much determined by their personal and their environmental situation (Syafruddin et al., 2013). So that, the declining performance of agricultural agents is closely related to the situations that do not allow them to do counselling activities like in normal situate.

The role of the extension agent during the COVID-19 pandemic has not functioned optimally, with only $11.9 \%$ of the respondents saying they had received ongoing counselling, while the rest were rarely or never visited. This was due to the 'work from home' policy which is currently being implemented. The role of extension needs to be given more priority in this period of the new normal. The role of these agents should not simply to provide information about cultivation techniques or health protocols during the COVID-19 pandemic but also to motivate the farmers to continue working. For this reason, extension measures are needed to provide encouragement so that the farmers are able to accept all the uncertainties about when the COVID-19 pandemic will end, thus reducing their anxiety and stress, as well as helping them to understand that the rice-field is not a dangerous place to carry out their activities, as long as they remain alert and follow the health protocols.

\section{CONCLUSIONS}

This research showed that throughout the COVID-19 pandemic, almost all farmers continued to carry out their agricultural activities. Some farmers had implemented the health protocols. According to farmers' opinion about agricultural activities, they mostly stated that doing the agricultural activities will make them healthier. In their opinion about COVID-19, most farmers behave normally, while the rest feel worried. Agricultural extension activities are constrained and hampered by the implementation of physical and social distancing protocols, especially regarding the large-scale social restrictions. Seeing the psychological condition of farmers, most of them were continue to cultivate food crops and are only slightly worried about the COVID-19 pandemic in farming. It gives hope for the sustainability of agricultural production in a new normal period.

\section{REFERENCES}

Acharibasam, J. W., \& Anuga, S. W. (2018). Psychological distance of climate change and mental health risks assessment of smallholder farmers in Northern Ghana: Is habituation a threat to climate change? Climate Risk Management, 21, 16-25. https://doi.org/ 10.1016/j.crm.2018.04.002

Akter, M., Fan, L., Rahman, M. M., Geissen, V., \& Ritsema, C. J. (2018). Vegetable farmers' behaviour and knowledge related to pesticide use and related health problems: A case study from Bangladesh. Journal of Cleaner Production, 200, 122-133. https://doi.org/ 10.1016/j.jclepro.2018.07.130

Al-Rabiaah, A., Temsah, M. H., Al-Eyadhy, A. A., Hasan, G. M., Al-Zamil, F., Al-Subaie, S., Alsohime, F., Jamal, A., Alhaboob, A., Al- 
Saadi, B., \& Somily, A. M. (2020). Middle East Respiratory Syndrome-Corona Virus (MERS-CoV) associated stress among medical students at a university teaching hospital in Saudi Arabia. Journal of Infection and Public Health, 13(5), 687-691. https:// doi.org/10.1016/j.jiph.2020.01.005

Annisa, D. F., \& Ifdil. (2016). Konsep kecemasan (anxiety) pada lanjut usia (lansia). Konselor, 5(2), 93-99. https://doi.org/10.24036/0201652 6480-0-00

Barcaccia, G., D'Agostino, V., Zotti, A., \& Cozzi, B. (2020). Impact of the SARS-CoV-2 on the Italian agri-food sector: An analysis of the quarter of pandemic lockdown and clues for a socio-economic and territorial restart. Sustainability (Switzerland), 12(14). https:// doi.org/10.3390/su12145651

Bennett, K. (2016). An exploratory study of the effects of stress and fatigue on Irish farm safety (issue March). Dublin Business School. Retrieved from https://esource.dbs.ie/handle/ $10788 / 3122$

Centre for Disease Control and Prevention. (2020). Coping with Stress. Retrieved from https://www.cdc.gov/coronavirus/2019ncov/daily-life-coping/managing-stress-anxie ty.html

Clark, L. A., Watson, D., \& Leeka, J. (1989). Diurnal variation in the positive affects. Motivation and Emotion, 13(3), 205-234. https://doi.org/10.1007/BF00995536

Cohen, S., \& Pressman, S. D. (2006). Positive affect and health. Current Directions in Psychological Science, 15(3), 122-125. https://doi.org/10.1111/j.0963-7214.2006.004 20.x

Djalante, R., Lassa, J., Setiamarga, D., Sudjatma, A., Indrawan, M., Haryanto, B., Mahfud, C., Sinapoy, M. S., Djalante, S., Rafliana, I., Gunawan, L. A., Surtiari, G. A. K., \& Warsilah, H. (2020). Review and analysis of current responses to COVID-19 in Indonesia: Period of January to March 2020. Progress in Disaster Science, 6, 100091. https://doi.org/ 10.1016/j.pdisas.2020.100091

Effendi, D. I., Lukman, D., Eryanti, D., \& Muslimah, S. R. (2020). Advokasi psikologis bagi masyarakat terpapar pandemi covid-19 berbasis religious e-counseling. Retrieved from http://digilib.uinsgd.ac.id/30709/1/Advo kasi\%20Psikologis\%20Bagi\%20Masyarakat \%20Terpapar\%20Pandemi\%20Covid-19.pdf

El Sheikh, T. M., El-Hammady, H. Y., Omar, A. S., \& Gebril, K. L. (2017). A descriptive study of the characteristics and systems of geese production in Sohag Governorate. Egyptian Poultry Science Journal, 37(3), 951-968. https://doi.org/10.21608/epsj.2017.7745

Haqi, M. H., Has, E. M. M., \& Bahiyah, K. (2019). Gambaran status mental (stres, kecemasan, dan depresi) pada korban pasca gempa berdasarkan periode perkembangan (remaja, dewasa, dan lansia) di Desa Pendua Kabupaten Lombok Utara. Psychiatry Nursing Journal (Jurnal Keperawatan Jiwa), 1(1), 2935. http://dx.doi.org/10.20473/pnj.v1i1.13013

Harlianty, R. A., Widyastuti, T., Mukhlis, H., \& Susanti, S. (2019). Study on awareness of covid-19, anxiety and compliance on social distancing in indonesia during coronavirus disease 2019 (COVID-19) pandemic [Preprints]. Pp. 1-16. https://doi. org/10.21203/rs.3.rs-44598/v1

Hossain, S. T. (2020). Impacts of COVID-19 on the agri-food sector: Food security policies of Asian productivity organization members. Journal of Agricultural Sciences - Sri Lanka, 15(2), 116-132. https://doi.org/10.4038/jas. v15i2.8794

Jones, C. L., Jensen, J. D., Scherr, C. L., Brown, N. R., Christy, K., \& Weaver, J. (2015). The health belief model as an explanatory framework in communication research: Exploring parallel, serial, and moderated mediation. Health Communication, 30(6), 566-576. https://doi.org/10.1080/10410236.2 013.873363

Kahambing, J. G. S., \& Edilo, S. R. (2020). Stigma, exclusion, and mental health during COVID19: 2 cases from the Philippines. Asian Journal of Psychiatry, 54, 102292. https://doi. org/10.1016/j.ajp.2020.102292

Lemke, M. K., Apostolopoulos, Y., \& Sönmez, S. (2020). Syndemic frameworks to understand the effects of COVID-19 on commercial driver stress, health, and safety. Journal of Transport and Health, 18. https://doi.org/10.1016/j.jth. 


\subsection{7}

Lindfors, P., \& Lundberg, U. (2002). Is low cortisol release an indicator of positive health? Stress and Health, 18(4), 153-160. https://doi. org/10.1002/smi.942

Lumban Gaol, N. T. (2016). Teori stres: stimulus, respons, dan transaksional. Buletin Psikologi, 24(1), 1-11. https://doi.org/10.22146/bpsi.11 224

Lutfey, K., \& Wishner, W. (1999). Beyond "compliance" is "adherence". Improving the prospect of diabetes care" Diabetes Care, 22(4), 635-639. https://doi.org/10.2337/ diacare.22.4.635

Mahmud, R., \& Uyun, Z. (2016). Studi deskriptif mengenai pola stres pada mahasiswa praktikum. Indigenous: Jurnal Ilmiah Psikologi, 1(2), 52-61. https://doi.org/ 10.23917/indigenous.v1i1.4970

Mutiarachmah, D., \& Maryatmi, A. S. (2019). Hubungan antara regulasi diri dan psychological well-being dengan kecemasan dalam menghadapi dunia kerja pada mahasiswa tingkat akhir jurusan Kesejahteraan Sosial UIN Syarif Hidayatullah Jakarta. IKRA-ITH HUMANIORA : Jurnal Sosial dan Humaniora, 3(3), 163-177. Retrieved from https://journals.upi-yai.ac.id/ index.php/ikraith-humaniora/article/view/688

Nandini, D. A. (2016). Kontribusi optimisme terhadap kebahagiaan pada karyawan. Jurnal Psikologi, 9(2), 187-196. Retrieved from https://ejournal.gunadarma.ac.id/index.php/ps iko/article/view/1557\#: :text=Sayangnya\%2 C\%20di\%20Indonesia\%20masih\%20banyak, yang\%20tidak $\% 20$ bahagia $\% 20$ dengan $\% 20 \mathrm{pe}$ kerjaannya.\&text=Artinya\%20optimisme $\% 20$ memiliki\%20kontribusi\%20yang,merupakan \%20faktor\%20lain\%20diluar\%20penelitian.

Nugraheny, D. E. (2020). Trend covid-19 di desa lebih baik dari kota, Mengapa?. Retrieved from https://nasional.kompas.com/read/2020/ 08/27/07501261/tren-covid-19-di-desa-lebihbaik-dari-kota-mengapa?page $=$ all

Pragholapati, A. (2020). New normal "Indonesia" after covid-19 pandemic. PsyArXiv, 2019, 1-6. https://doi.org/10.31234/osf.io/7snqb

Pressman, S. D., \& Cohen, S. (2005). Does positive affect influence health? Psychological Bulletin, 131(6), 925-971. https://doi.org/ 10.1037/0033-2909.131.6.925

Sadaghiani, N. S. K., \& Sorkhab, M. S. (2013). The comparison of coping styles in depressed, anxious, under stress individuals and the normal ones. Procedia - Social and Behavioral Sciences, 84, 615-620. https://doi.org/10.1016 /j.sbspro.2013.06.613

Setiati, S., \& Azwar, M. K. (2020). COVID-19 and Indonesia. Acta Medica Indonesiana, 52(1), 84-89. Retrieved from http://www.acta medindones.org/index.php/ijim/article/view/1 426

Shammi, M., Bodrud-Doza, M., Towfiqul Islam, A. R. M., \& Rahman, M. M. (2020). COVID19 pandemic, socioeconomic crisis and human stress in resource-limited settings: A case from Bangladesh. Heliyon, 6(5). https://doi.org/ 10.1016/j.heliyon.2020.e04063

Simha, P., Lalander, C., Vinnerås, B., \& Ganesapillai, M. (2017). Farmer attitudes and perceptions to the re-use of fertiliser products from resource-oriented sanitation systems The case of Vellore, South India. Science of the Total Environment, 581-582, 885-896. https:// doi.org/10.1016/j.scitotenv.2017.01.044

Smith, D. F. (1975). The functions of work. Omega, 3(4), 383-393. https://doi.org/10.1016 /0305-0483(75)90002-X

Snyder, C. R. E., \& Lopez, S. J. E. (2002). Handbook of positive psychology (Oxford library of psychology). New York: Oxford University Press, Inc. Retrieved from http://ldysinger.stjohnsem.edu/@books1/Snyd er_Hndbk_Positive_Psych/Snyder_Lopez_Ha ndbook_of_Positive_Psychology.pdf

Steptoe, A., Wardle, J., \& Marmot, M. (2005). Positive affect and health-related neuroendocrine, cardiovascular, and inflammatory processes. Proceedings of the National Academy of Sciences of the United States of America, 102(18), 6508-6512. https://doi.org/10.1073/pnas.0409174102

Syafruddin, Hariadi, S. S., \& Wastutiningsih, S. P. (2013). Kinerja penyuluh pertanian berdasarkan faktor personal dan situasional. Jurnal Psikologi, 40(2), 240-257. Retrieved from https://jurnal.ugm.ac.id/jpsi/article/view 
16980

Varalakshmi, R., \& Swetha, R. (2020). Covid-19 lock down: People psychology due to law enforcement. Asian Journal of Psychiatry, 51, 102102. https://doi.org/10.1016/j.ajp.2020.10 2102

Waridin. (2015). Capacity building to boost food-crop production: Case of Central Java of Indonesia. Asia-Pacific Journal of Rural Development, 25(2), 111-118. https://doi.org/ $10.1177 / 1018529120150207$

World Health Organization. (2020). Mental health and psychosocial considerations during COVID-19 outbreak, 18 March 2020. World Health Organization, pp. 1-6. Retrieved from https://apps.who.int/iris/handle/10665/331490

Yulianti, D., Meutia, I. F., Sujadmiko, B., \&
Wahyudi. (2020). Indonesia' crisis response to COVID-19 pandemic: from various level of government and network actions to policy. Journal of Public Administration, Finance and Law, 17, 34-48. Retrieved from http://www. jopafl.com/uploads/issue17/INDONESIA_CR ISIS_RESPONSE_TO_COVID19_PANDEM IC_FROM_VARIOUS_LEVEL_OF_GOVE RNMENT_AND_NETWORK_ACTIONS_T O_POLICY.pdf

Zariayufa, K., Ninin, R. H., \& Widiastuti, T. R. (2019). Hubungan belief in afterlife dengan kecemasan terhadap kematian (Studi pada individu muslim usia 18-21 tahun). Psikoislamedia Jurnal Psikologi, 4(1), 84104. Retrieved from https://jurnal.ar-raniry .ac.id/index.php/Psikoislam/article/view/6352 